\title{
Urban air pollution in China: risk perceptions and destination image
}

Prof Susanne Becken

Griffith Institute for Tourism

Griffith University, Australia

Email: s.becken@griffith.edu.au

Dr Xin Jin

Griffith Institute for Tourism

Griffith University, Australia

Email: x.jin@griffith.edu.au

Dr Chen Zhang

Shanghai Normal University

Shanghai, China

Email: zcdh926@126.com

Prof Jun Gao

Shanghai Normal University

Shanghai, China

Email: gaojun@shnu.edu.cn

Please cite as: Becken, S. Jin, X., Chen, Z., \& Gao, J. (2016). Urban air pollution in China: risk perceptions and destination image. Journal of Sustainable Tourism. 


\title{
Urban air pollution in China: Destination image and risk
}

\section{perceptions}

\begin{abstract}
Inbound tourist arrivals into China have been declining in recent years, possibly in response to increasing levels of urban air pollution. To examine Westerners' contemporary views on China as a travel destination, with a particular focus on air pollution, this research surveyed 600 US and Australian residents. An online panel survey collected data on cognitive and affective destination image, cognitive and affective risk perceptions, intention to visit China and key demographic variables. The findings show that, while China's cognitive image attributes were perceived positively, potential travelers expressed negative views about travel risks in China in general and about air quality in particular. Importantly, feelings towards the risk of air quality had a significant negative impact on destination image as well as intention to visit China. The research contributes to theory by highlighting the importance of considering affective risk perceptions in destination image studies. While some market segments seemed less sensitive to air pollution than others, this paper concludes that unless China proactively addresses the problem of air pollution, for example by seeking to stimulate positive feelings, international arrivals may continue to be compromised.
\end{abstract}

\section{Introduction}

China is a large country with beautiful scenery, abundant heritage resources and distinctive cultures, and a growing interest in sustainable tourism (Xu et al., 2014). However, China is suffering from increasingly concerning levels of air pollution in its major urban centres. Smog - a result of pollution levels and specific weather conditions - is now an important topic of public debate, and daily measurements are communicated in the media (Wang, Sun, Yang \& Yuan, 2015). The new standards set by the Chinese Government for the concentration of ozone $\left(\mathrm{O}_{3}\right)$ and PM2.5 (particulate matter of 2.5 micro meters in diameter and smaller) over a period of eight hours, are frequently exceeded (World Health Organisation Western Pacific Region, 2015), with some cities reaching dangerous levels that are posing serious health concerns (Wang et al., 2015).

At the same time, domestic tourism in China is growing at a fast rate and the country is also seeking to develop its international tourism market. According to statistics by the United 
Nations World Tourism Organization (UNWTO, 2015), China is now the fourth largest travel destination in the world with 55.6 million international arrivals in the year 2014. However, inbound arrivals into China have been stagnating since 2007 and decreased in the last few years (e.g. $-3.5 \%$ between 2012 and 2013, and $-0.1 \%$ between 2013 and 2014, UNWTO, 2015), in particular from regions other than Hong Kong, Macau and Taiwan (CNTA, 2014). The exact reasons for the decline are unknown, but it has been suggested that increasing concern about environmental conditions in China, in particular the poor air quality in major cities, is undermining China's popularity as a travel destination $(\mathrm{Li}, 2014)$ and aspirations to establish as a sustainable tourist destination. Others have expressed doubt that air quality and haze have detrimental effects on arrivals, arguing that air quality has deteriorated only after the drop in inbound tourism began (Li, 2014). To date, no empirical research has examined the role air quality might play in shaping people's perceptions about China as a destination, and their intention to visit.

The image of a country as a travel destination is an important factor in tourists' decision making. Communicating a positive destination image is central to successful destination marketing (Konecnik, 2002). Environmental quality has been identified as a key element amongst a range of image attributes. Most often, however, research and practice concerning destination image have focused on the positive aspects of destination image (Pike \& Ryan, 2004), disregarding negative attributes that could erode the image. Examples of such negative aspects include social problems (e.g. widespread poverty), environmental disasters or pollution (Ryan, Gu \& Chon, 2010), or political tensions and conflict. Gartner and Shen (1992), for example, investigated the impacts of news coverage of the Tiananmen Square conflict on the image of China, finding that people perceived China more negatively after the incident, especially in dimensions such as 'safety and security', and 'receptiveness of local people to tourists'. It is also possible that negative image has a discernible effect on tourists' 
attitudes and behaviours in relation to sustainable tourism (Line \& Hanks, 2015), constituting an important feedback loop that undermines long-term sustainability.

Very little is known about the destination image of China (Gu \& Ryan, 2008), including its environmental attributes. This research therefore explores how China is perceived as a destination in general, and with a particular focus on air quality. Two markets are examined in detail: the US and Australia. Both countries constitute long-haul markets for China, and have been declining in recent years (CNTA, 2014). The US and Australia are the only two English-speaking source countries among China's top ten inbound markets. A joint survey of US and Australian residents, representing potential travellers to China, therefore presented an opportunity to understand Westerners' views on China as a travel destination. Earlier research had established that travellers from Western countries were more sensitive to air pollution in Hong Kong than those from Asian origins (Law \& Cheung, 2007). To investigate the role air pollution plays in destination image, risk perceptions and travel intention, this research follows a recent move towards integrating the destination image and risk literatures (Chew \& Jahari, 2014; Lepp, Gibson \& Lane, 2011; Williams \& Baláž, 2015). This research draws on both bodies of knowledge to advance our understanding of the role of risk perceptions - both cognitive and affective - in shaping destination image, and ultimately intention to visit. Findings from this research will also provide additional rationale for Chinese decision makers to urgently address the urban air pollution problem, and help destination marketing organizations consider actions to remedy negative effects.

\section{Linking destination image and risk perception studies}

The way a country or region is perceived is of major importance to its success as a tourist destination. The tourism literature has explored these perceptions through two major strands of research: destination image and destination risk. These are typically not integrated: research on image tends to focus on positive aspects of a destination, whereas the risk 
literature explores aspects that cause concern, fear or worry (Chew \& Jahari, 2014; Jeuring \& Becken, 2013). In other words, destination image research focuses on why tourists would like to visit a place, and risk-related research explores why tourists might choose not visit. In the following, insights from each of these research traditions are synthesized and integrated into a common theoretical framework.

\subsection{Destination image}

Tourism destination image is one of the most researched topics in the field of tourism (Echtner \& Ritchie, 2003; Fakeye \& Crompton, 1991; Gartner, 1994). Destination image relates to overall impressions of a place (Crompton, 1979), with cognitive and affective dimensions interacting in complex ways. Cognitive components describe a set of beliefs that people have about a destination. These beliefs are typically formed by processing and integrating information from various sources over time (Crompton, 1979; del Bosque \& Martin, 2008). Affective components of destination image refer to the appraisal of positive, negative or neutral feelings towards aspects of a destination (Baloglu \& Brinberg, 1997; Baloglu \& McCleary, 1999; Beerli \& Martín, 2004; Ward \& Russell, 1981). While cognitive evaluations appear to influence affective ones in a hierarchical way (Baloglu \& McCleary, 1999; Gartner, 1994), each dimension makes a unique contribution to destination image and can be measured separately. Gartner (1994) and Dann (1996) conceptualised a third dimension; namely conative destination image. Conation relates to processes that integrate cognitive and affective aspects of the mind to turn thoughts and feelings into behaviours. In the context of tourism, conative image can be interpreted as the likelihood of visiting a destination (see 'Intention' in Figure 1).

Cognitive aspects of destination image are usually assessed on a set of attributes that correspond to the resources or attractions that a tourist destination can offer. Beerli and Martín (2004) classified 24 attributes into nine dimensions: natural resources; general 
infrastructure; tourism infrastructure, tourism leisure and recreation; culture, history and art; political and economic factors, natural environment, social environment; and the atmosphere of the place. The choice of specific attributes used in a research instrument is destinationspecific (Gallarza et al., 2002), and typically includes a set of attractions and supporting infrastructure. The affective components of destination image have typically been measured through a wide range of adjectives that describe feelings about a particular place. Often, measurement of affective image is based on Russell, Ward and Pratt's (1981) four-dimension response grid, namely “pleasant/ unpleasant”, "relaxing/distressing”, “arousing/sleepy”, and “exciting/gloomy". Russell et al. (1981) suggested that the affective quality of places can sufficiently be captured by two bipolar dimensions, namely "pleasant-unpleasant" and “arousing-sleepy".

Tourists form an image of a destination through a number of steps, including the shaping of an initial organic image, which is then refined into an induced image by further processing of information, for example in preparation of a visit. Images become more realistic and differentiated to include specific aspects of the destination when people have visited a place (Fakeye \& Crompton, 1991). People who have not visited tend to focus on generic attributes, functional aspects and common features (Echtner \& Ritchie, 1993). The importance of wordof-mouth has been recognised, and the substantial increase in the use of social media means that exchanges between different types of travellers (including those who travel infrequently) are becoming more influential, especially in forming an organic image and reinforcing stereotypes (Chen, Lai, Petrick \& Lin, 2016).

Destination image formation is influenced by personal factors that reflect the characteristics of the perceiver (Baloglu \& McCleary, 1999). Several studies established that age, gender and educational level were differentiating factors in destination image (Beerli \& Martín, 2004; Stern \& Krakover, 1993), although findings are not fully conclusive. In addition to 
demographic variables, previous research reported that geographic distance to the destination affects image; markets that are closer to the destination have more detailed images than geographically distant markets (Gartner, 1994).

\subsection{Risk perceptions}

Most destination image studies focus on positive attributes, even though, in theory, negative aspects are also likely to shape image. Safety concerns by tourists can erode destination image with long-lasting effects if they remain unaddressed (Sirakaya, Sheppard, \& McLellan, 1997). For example, research on air quality in Hong Kong revealed that, while people held neutral views before their trip (Law \& Cheung, 2007), they expressed concern and dislike about both outdoor and indoor air quality following their visit (Cheung \& Law, 2001). Improved media coverage and information accessibility has shown to proliferate negative views and awareness of issues such as terrorism, political instability, and health concerns amongst travellers (Sönmez \& Graefe, 1998).

Travel-related risks are manifold and include natural disasters, hygiene, diseases, terrorism, political instability, crime and accidents, cultural and language difficulties, and environmental quality (Maser \& Weiermair, 1998; Reisinger \& Mavondo; 2006; Richter, 2003). Risk in this context relates to perceptions of probabilities and adverse outcomes of particular tourism products, services or events. Destinations that are perceived as unsafe have been found to be associated with a lower likelihood of visitation compared with those that are believed to be safe (Reisinger \& Mavondo, 2006; Sirakaya et al., 1997). Research on risk perceptions has also focused on whether tourists avoid or seek destinations with particular risks (Lepp \& Gibson, 2003; Sönmez \& Graefe, 1998).

Different schools of thought exist on how tourists conceptualise risk. The rationalist approach considers that the tourist seeks to maximise knowledge and decrease uncertainty to reduce the likelihood of negative events or outcomes (Williams \& Baláž, 2015). Risk perceptions are 
therefore also linked to information search and protective behaviour (Jeuring \& Becken, 2013). The rationalist approach reflects a focus on cognitive processes and sees risk as objective and observable (Trumbo et al., 2016). In contrast, the social constructionist approach (aligned with postmodernism) assumes that tourists combine fact-based decision making with intuition in a rather fluid way. Risks are constantly negotiated and interpreted in a complex process of intellectual and emotional assessments (Williams \& Baláž, 2015). Construction of risk is therefore embedded in the socio-cultural context and background of the individual (Douglas \& Wildavsky, 1982; Shakeela \& Becken, 2015).

The notion of risk-as-feeling was conceptualised by Loewenstein Weber, Hsee and Welch (2001), who challenged existing cognitive theories of risk perceptions and decision making, and suggested that 'affect' explains wide range of risk-related decisions. Building on this notion, research has identified that perceptions of the increased likelihood of a hazard can trigger affective responses, including fear, dread or worry (Shim \& You, 2015). Worry, in turn, has been found to lead to enhanced protective behaviour, which may influence destination choice and avoidance of places that are perceived as risky (Larsen, Brun \& Øgaard, 2009). Loewenstein et al. (2001) noted that affective risk perceptions are particularly relevant for risks that seem to be not controllable. Taking a more holistic approach to risk, a dual-process of conceptualising perceptions has been proposed, whereby cognitive and affective aspects are covered in related but distinct scales (Trumbo et al., 2016). Risk perceptions - both cognitive and affective - can influence foundation beliefs about a nation or destination, and as a result shape destination image and intention to visit (Nadeau, Heslop, O’Reilly \& Luk, 2008).

Similar to destination image, research on risk perceptions found that a range of factors mediate how people perceive or 'feel' about risks (Williams \& Baláž, 2015). Key factors include gender, age and previous travel experience, although the nature of their influence 
depends on the particular context. Women often have more negative perceptions of risk than men, for example in relation to health and food (Lepp \& Gibson, 2003) or exposure to violence in China (Qi et al., 2009). In a study on risk perceptions related to travel to the Olympic Games in Beijing, Schroeder et al. (2013) discovered that younger travellers from the US had higher risk perceptions than older visitors, possibly because of a lack of knowledge and experience. This research further builds on the above studies by investigating differences in risk perceptions (cognitive and affective) amongst potential travellers from the US and Australia to China, and their impact on destination image (cognitive and affective) and intention to visit.

\subsection{Integrated framework}

Examining the positive and negative attributes of a destination, as well as analysing travellers' risk perceptions of a particular place are critical for understanding destination competitiveness. Studying destination image and risk perceptions in conjunction to enable destination managers to address negative perceptions has been suggested by Sönmez as early as 1998. However, only recently have researchers called for a better integration of destination image research with the risk literature (Chew \& Jahari, 2014; Qi, Gibson \& Zhang, 2009; Schroeder, Pennington-Gray, Kaplanidou \& Zhan, 2013). Taking a broader view of both image and risk might be particularly important when a destination develops a reputation for being unsafe or risky, as found in the case of Cape Town, South Africa (George, 2003).

Two previous studies have explicitly integrated destination image and risk perception approaches to understand the "role of perceived risks in re-forming destination image [as] one of the least studied areas" (Chew \& Jahari, 2014, p. 383). Lepp et al. (2011) researched the impact of exposure to Uganda's national tourism marketing website on risk perceptions. The authors found that perceptions of Uganda as a destination were significantly more positive after having seen tourism related marketing material, compared with a control group 
whose risk perceptions were stable. The second study examined the relationship between three types of perceived travel risks, destination image and intention to visit in the context of tourism in Japan, following the Fukushima disaster (Chew \& Jahari, 2014). The study provided empirical evidence that both cognitive and affective destination images act as mediators between risk and intention to visit. More specifically, the perceived sociopsychological and financial risks of visiting Fukushima were significant in re-forming destination image. Perceived physical risk (e.g. sickness or injury) only affected travel intention directly but did not influence destination image. The authors concluded that while integrating image and risk perceptions remain two distinct concepts it is very useful to integrate them into one study.

In the case of China, the predominant images in the past were beautiful heritage, exotic culture and landscape, and high standard hotels (Santos, 1998). Moving to the new millennium, and at a time of greater Internet access and use of social media, the depictions of China have become more diverse, often mixed with contrasting representations and a polarisation between nature and history on the one hand, and urbanization, progress and pollution on the other (Xiao \& Mair, 2006; Shani, Chen, Wang \& Hua, 2010). It appears that China's destination image continues to be shaped by stereotypical content, including both positive (e.g. historical sites, food, culture) and negative (e.g. communism, language barriers) aspects, all of which influence perceptions amongst important source markets such as the US (Pan \& Li, 2011). Stereotypes were found to negatively influence affective image, and possibly travel intention (Chen et al., 2016). However, changes in affective image might be easier to achieve than those related to cognitive image (Li, Pan, Zhang and Smith, 2009). For example, the Beijing 2008 Olympic promotion video positively influenced China's image and subjects' behavioural intentions (Shani et al. 2010), and a brief online search for the purpose 
of travel-planning to China could significantly increase subjects' affective image of China (Li et al., 2009).

More recent studies published in Chinese identified major problems related to perceptions of China, including tourism infrastructure (e.g., signage and toilet), communication (language barrier), and environmental issues (Gao, Ma \& Wu, 2010). Poor air quality and transportation topped the list of risk items perceived by inbound tourists to China (Cheng, Zhou, Wei \& $\mathrm{Wu}, 2015)$. However, little is known about how international tourists perceive the risk of air pollution in China, either from a cognitive or affective perspective. Global media coverage on Chinese air pollution is extensive (e.g. Zand, 2015), including the prominent example of a 100-minute documentary on air pollution entitled 'Under the Dome' that went viral both within and outside China. Media coverage of environmental hazards, especially poor air quality such, has been found to influence people's perceptions (Oltra \& Sala, 2014), and it is therefore conceivable that potential travellers to China have elevated risk perceptions of travelling to China. These perceptions could impact on destination image (cognitive and affective), as well as on the intention to visit China.

Based on the international literature, and with a particular view of China as a travel destination, an integrated framework of destination image and risk perceptions, and their influences on intention to visit, is proposed (Figure 1). Specifically, and referring to potential travellers from the US and Australia, the following hypotheses will be tested:

H1: Cognitive risk perceptions negatively affect cognitive destination image; with H1a focusing on 'attractions', and H1b relating to 'infrastructure' as subsets of cognitive image.

$\mathrm{H} 2$ : Cognitive risk perceptions negatively influence affective destination image.

H3: Feelings towards air quality (as affective risk perception) negatively affect cognitive destination image; with $\mathrm{H} 3 \mathrm{a}$ focusing on 'attractions', and $\mathrm{H} 3 \mathrm{~b}$ relating to 'infrastructure'. H4: Affective risk perceptions negatively influence affective destination image. 
H5: Cognitive risk perceptions negatively impact intention to visit.

H6: Affective risk perceptions negatively impact intention to visit.

H7: Cognitive destination image positively influences intention to visit; with $\mathrm{H} 7 \mathrm{a}$ focusing on 'attractions' and $\mathrm{H} 7 \mathrm{~b}$ relating to 'infrastructure'.

H8: Affective destination image positively influences intention to visit.

\section{Insert Figure 1 about here}

\section{Methodology}

\subsection{Instrument development}

Since research on destination image is well established with a range of tested scales (Beerli \& Martín, 2004; Russell et al., 1981), a quantitative approach was taken. A survey was designed to incorporate questions concerning destination image, risk perceptions, and information on respondents. A draft of the survey instrument was distributed in paper-format to 20 colleagues and other contacts for pilot testing. Based on the results and the constructive feedback received, the questionnaire was modified slightly to improve its clarity and scale readability. The pilot test also established that the survey took about 10 minutes to complete. In the first part of the questionnaire, two key questions examined US and Australian residents' perceptions of mainland China as a travel destination. First, a 12-item scale captured the cognitive dimension of destination image based on tested measurement scales employed by Beerli \& Martín (2004) and Gallarza et al. (2002). The attributes covered tourist attractions (interesting cultural, historical, and natural attractions), and the quality of the supporting infrastructure of the hospitality industry and its environment (good shopping facilities, good night life and entertainment, varied gastronomy/appealing local food, suitable accommodation, fast/convenient transportation, friendly people, good hygiene standard, clean 
air, unpolluted natural environment). Respondents were asked to rate China as a travel destination according to these attributes by indicating their level of agreement on a 5-point Likert scale, where 1= Strongly disagree; $2=$ Disagree; $3=$ Neutral; $4=$ Agree ; and 5= Strongly agree.

Informed by previous research, affective destination image was measured through a semantic-difference scale consisting of five affective image attributes: displeased - pleased, bored - stimulated, distressed - relaxed, indifferent - exciting, physically and mentally unwell - well (Baloglu \& Brinberg, 1997; Russell et al., 1981). The wording was modified slightly in response to feedback obtained in the pilot testing. A 5-point semantic-differential scale was used for all five bipolar scales where the negative poles were assigned the smallest values and the positive ends reflected the highest value.

The second part of the survey explored people's views on five travel risks related to China, namely air quality, transportation safety, food quality, standards of hygiene and general safety. Respondents were asked to indicate if they see each of the factors as a travel risk on a 5-point scale, where $1=$ very low risk; $2=$ low; $3=$ neutral; $4=$ high; and 5= very high risk. While these are similar to some of the cognitive image items explored in the first part of the questionnaire the framing in this question differs in that it specifically examines people's perspective on whether these items pose a personal risk, rather than just representing a destination attribute. In addition to the cognitive risk perceptions, respondents were asked how they felt when they thought of China's air quality. The measurement of this affective dimension of risk perceptions followed the format of affective destination image. Five bipolar scales were used: sick - healthy, frightened - reassured, unconcerned - concerned, out of control - under control, and unacceptable - acceptable.

The third part collected information on respondents' international travel experience, including previous visits to China, and the likelihood of them visiting China within the next 
two years. Further, key demographic variables, including age, gender, education, travel experience, were collected.

\subsection{Sample and data collection}

To collect data from respondents in the US and Australia it was decided that an online panel survey would present the most cost-effective approach. Using online panels as a sampling approach is becoming a popular global phenomenon in academic and commercial research (Baker et al., 2010; Lawton \& Weaver, 2015). In countries like the US and Australia, with Internet penetration rates of $86.9 \%$ and $94.1 \%$, respectively (Internet World Stats, 2014), this approach seemed suitable. An online panel is "a sample database of potential respondents who declare that they will cooperate with future [online] data collection if selected" (International Organization for Standardization 2009, cited in Baker et al., 2010). A panel could serve as a sampling frame, especially for studies with inherent problems to produce precise estimates of population perceptions. There could be significant coverage error and high level of non-responses in building a nonprobability panel (Baker et al., 2010). Thus, some attempts were made to reduce bias through: 1) choosing a reliable panel company (Qualtrics), reputable for having a relatively large and quality (with valid email addresses of participants who agreed to be surveyed) database, so that the quality of the panel (sampling frame) is assured to a certain degree; and 2) employing quota sampling to achieve a relatively demographically balanced and diversified sample, and 3) taking measures to reduce selfselection bias (as indicated below).

The final survey was sent out by Qualtrics on 20 November 2014 as an online selfadministered questionnaire to US and Australia panellists. The survey was open for two weeks although most surveys were completed within the first few days. The prompt completion of the survey is an indication of enthusiasm from the respondents' side. The sampling quota instruction was 300 for each country with an even gender split (in the data, 
even gender split was achieved overall but males slightly outnumbered females in the US and females slightly outnumbered males in Australia sample). Potential respondents to a Qualtrics survey were sent an invitation by email to inform them that this particular survey is for research purposes, how long the survey would take, and whether there were any incentives (in this study no incentives but a chance to voice their opinion were offered).

To reduce self-selection bias, no information on the survey topic was provided. In total, invitations for survey participation were sent out to 7,739 Qualtrics US panellists, of which 1623 clicked on the survey link, generating a potential response rate of about $20.9 \%$.

However, after the first 300 required full completions were captured, the survey website was closed (another 5 full responses were included right before shut-down). Thus, it is difficult to estimate the percentage of the 1623 panellist who dropped during the completion against those who did not have a chance to complete the survey due to closure of the website. In Australia, 3000 panellists were invited and 377 clicked on the survey link, generating a response rate of about $12.6 \%$. Again, after the first 300 full completions were captured, the survey was closed. Despite problems in terms of coverage and non-responses inherent in web-based surveys, the response rate (12.6\% and 20.9\%) of this survey is acceptable (Sills \& Wang, 2002), although non-probability sampling in general is a limitation.

\subsection{Data analysis}

Data were analysed using several techniques. Following analysis of key descriptive variables, confirmatory factor analysis (CFA) was conducted to validate the applicability of the scales for each latent variable in the context of this research and establish an overall measurement model. Next, a structural equation modelling (SEM) was performed to test if independent variables (i.e. risk perceptions, feelings toward air quality) have significant impact on dependent variables (i.e. cognitive image, affective image, and intention to visit). Finally, and in recognition of insights from previous research (insert ref/s) that both image and risk 
perceptions differ for different groups, ANOVAs were performed. SPSS 22.0 and AMOS 22.0 were utilized for the analyses. Maximum likelihood method was used for model estimation. As answering each question in the online survey was set compulsory, there were no missing values in the data. Multivariate normality of the data was checked by checking the distribution of each indicator (variable). The data were found to have an approximate normal distribution according to the report of skewness and kurtosis of each variable, as the values were all within the $+/-2$ range.

\section{Results}

\subsection{Respondents' profile}

Qualtrics was instructed to collect an equal number of male versus female, as well as US and Australia respondents. With regard to age groups, data skewed toward senior groups: $25.4 \%$ were from the 25-39 group, $23.0 \%$ from the 40-54 group, and $46.9 \%$ were aged above 55 years (Table 1). Most respondents were well educated: $43.6 \%$ completed a university degree and $12.6 \%$ completed a postgraduate degree. Travel experience was lower amongst US respondents (53.8\% had not been overseas) compared with Australian respondents $(27.5 \%)$. Only $12.1 \%$ of US respondents had previously visited China. The corresponding proportion was $27.9 \%$ for Australian survey participants. With regard to intending to visit China in the next three years, $21.6 \%$ of US and $24.3 \%$ of Australian respondents were positive (probably to definitely will).

\section{Table 1 about here}

\subsection{Image and risk perceptions}

The survey demonstrates that China enjoys a positive image in relation to culture, heritage and scenery - the core items making up cognitive image. Mean values of all three items were over 4.2 on a 5-point Likert scale (Table 2). Cognitive image items that capture respondents' views on tourism infrastructure were rated slightly lower, but still positive. Respondents did 
not agree with China having an unpolluted environment or good air (mean values of 3.11 and 2.77, respectively); thus displaying awareness of environmental problems in China. In terms of affective image, respondents rated all items around 3.5, indicating a slight tendency towards positive feelings.

Respondents generally perceived that there were a number of travel risks when visiting China, with all mean values being above 3.0 on a 5-point Likert scale (Table 2). Most prominently, air quality and hygiene were perceived as a travel risk. When asked how people felt about air pollution, respondents showed overwhelmingly negative feelings, with all items having a mean value below 2.78 out of a 5-point Likert scale. This finding indicates that, affectively, respondents are repulsed by air quality in China. When asked specifically, whether 'air quality will affect my decision to visit China', respondents indicated some effect with a mean value of 3.37 .

\section{Table 2 here}

\subsection{Confirmatory Factor Analysis}

This study took a two-step approach to analyse the relationships between risk, image and travel intention. First, CFA was performed to test the hypothesized relationships between the five latent variables and their proposed measurements (Table 2). The measurement model provided an indication that the constructs were unidimensional (Jöreskog, 1993). The overall measurement model, which allowed correlations among all five latent variables, presented a baseline to assess the fit of the structural model, as the proper specification of the overall measurement model is required for a structural model to have meaning (Anderson \& Gerbing, 1982; Hair, Anderson, Tatham, \& Black, 2010). Results show that the overall measurement model was viable. All factor loadings of the measurement items onto the latent variable that they were supposed to measure reached 0.7 , indicating good indicator reliability and convergent validity of these measures (Steenkamp \& van Trijp, 1991). The model fit indices 
indicated acceptable fit of the model $\left(\chi^{2}=724.55, \mathrm{df}=240, \chi^{2} / \mathrm{df}=3.019, \mathrm{GFI}=.908, \mathrm{CFI}=.955\right.$, RMSEA=.058). The reliability and validity of the measurement model were established by examining composite reliability, convergent and discriminant validity. Composite reliability (CR) values of all constructs were above 0.9 , indicating good construct reliability (Bagozzi \& Yi, 2011). AVE values of each construct exceeded 0.5, indicating good convergent validity. Discriminant validity was assured as the squared correlation between each pair of constructs was lower than the AVE for each of the two constructs (Fornell \& Larker, 1981). Table 3 reports the correlations, mean value, AVE, and CR of the latent variables. Thus, CFA analysis confirmed the factor structures of all the latent variables.

\section{Table 3 here}

\subsection{Structural model}

Based on the overall measurement model, the hypothesized causal relationships between independent and dependent variables were tested using structural equation modelling. In the SEM model, there were two independent latent variables (i.e. risk perception and feelings toward air quality), three latent dependent variables (i.e. cognitive image/infrastructure, cognitive image/attractions, affective image), and one dependent observed variable (intention to visit). The three destination image variables were also postulated as mediators (Chew \& Jahari, 2014) and assumed to impact on intention to visit.

In addition to these specified paths indicating possible causal relationships between independent and dependent variables, four correlations were added to the model. These correlations were between: 1) two independent latent variables (i.e., risk perception and feelings toward air quality, covariances $=.275$, correlations $=.31)$; 2) the error terms of cognitive infrastructure and cognitive attraction (covariances $=.511$, correlations $=.676) ; 3$ ) the error terms of affective image and cognitive infrastructure (covariances=.286, correlations $=.354$ ); and 4) the error terms of affective image and cognitive attraction 
(covariances $=.382$, correlations $=.506$ ). The first correlation is a default requirement of AMOS. The correlations of the error terms of the three constructs, namely attractions, infrastructure and affective image, were based on the modification indices generated by the AMOS output. The modification decreased the chi-square value and improved model fit indices, which could be well supported theoretically, as all the three scales are measures for destination image and theoretically should be correlated.

Table 4 denotes the path coefficients of the structural model. Model fit indices of the structural model $(\chi 2=895.10, \mathrm{df}=261, \chi 2 / \mathrm{df}=3.43, \mathrm{GFI}=0.9, \mathrm{CFI}=0.943, \mathrm{RMSEA}=0.063)$ ascertained that the model was plausible. The key finding is that the construct 'feelings towards air quality' has a significant impact on all dependent variables (Hypotheses 3, 4 and 6 validated), in particular on affective destination image. Risk perception also has a significant impact on affective destination image $(\mathrm{H} 2)$, albeit to a much lesser degree than 'feelings toward air quality'. Notably, risk perception does not have significant impact on cognitive image (attractions or infrastructure) or on intention to visit. Likewise, the two cognitive destination image factors do not have a significant impact on intention to visit. Only the affective image component has a strong significant impact on intention to visit (H8). Thus, the structural paths shown in the overall framework (Figure 1) indicate that affective destination image is the most influential factor for intention to visit, with 'feelings toward air quality’ being highly influential on affective destination image.

\section{Table 4 here}

\subsection{Differences between groups}

ANOVA and t-tests were performed to compare possible differences based on key variables identified in the literature. Results indicated statistically significant differences $(t \leq 0.01)$ between several groups (Table 5). Notably, the Australian group rated China's attractions higher $(\mathrm{t}=0.001)$, had a more positive affective image of China $(\mathrm{t}=0.009)$, and a higher 
intention to visit China ( $\mathrm{t}=0.005)$ than the US group. There were no significant differences (at the level of $\mathrm{t} \leq 0.01$ ) over risk perceptions and air quality feeling between US and Australian groups. Gender was not a major differentiator, although females felt less frightened of air quality than males $(\mathrm{t}=0.01)$. Younger demographics (25-39 group) had less negative risk perceptions of air pollution than the above 55 group $(\mathrm{t}=0.006)$, had a stronger intention to visit China than the above 55 group $(\mathrm{t}=0.000)$, but indicated a lower recognition of China's key attractions than the above 55 group $(\mathrm{t}=0.000)$. There were similar patterns between the 25-39 group and the 40-54 group, but not of the same significance.

Those who had visited China before rated China's attraction higher than those who had not $(\mathrm{t}=0.000)$. They also had a better affective image of China $(\mathrm{t}=0.000)$ and were more likely to re-visit China $(\mathrm{t}=0.000)$. But due to the difference in sample size, this result might need to be verified using a different sample. Travel experience emerged as a moderating factor on almost all factors. Frequent and occasional travellers rated China's attraction higher than the never travelled internationally group ( $\mathrm{t}=0.006$ and $\mathrm{t}=0.000$ respectively), and had a more positive affective image of China $(\mathrm{t}=0.000)$. Those who travelled frequently and occasionally felt generally more reassured and less concerned about air quality in China than those who never travelled internationally ( $\mathrm{t}=0.000$ and $\mathrm{t}=0.005$, respectively), highlighting the need to examine both travellers and non-travellers. In terms of travel risks, those who travelled occasionally perceived a higher risk than those who travelled frequently $(t=0.016)$ and those who never travelled internationally $(\mathrm{t}=0.007)$. Respondents, who reported to be frequent travellers, were also more likely than others to visit China (Table 5).

Overall, respondents indicated that air quality would affect their decision to visit China, but no significant differences were found within all sets of comparisons - by country, gender, age, travel experience, and have been/not been to China. 


\section{Discussion}

The problem of air pollution in tourist destinations is not unique to China (e.g. Paris, BBC News, 2014). Poor air quality has previously been linked to negative economic impacts as a result of decreased tourism activity (Anaman \& Looi, 2000; Sajjad, Noreen \& Zaman, 2014), and tourism has also been identified as a significant contributor to air pollution (Sáenz-deMiera \& Rosselló, 2013). This research makes several contributions to the literature and to sustainable tourism management.

First, this research shows that the image of China has been tainted by air pollution, likely fuelled by extensive international media reporting and organic discussions of the issue. More specifically, this research attests that a destination with an image of air pollution, like China (evidenced through affective image, and the two relevant items of cognitive image), would be considered less attractive as a travel choice. As a result, poor air quality may lead to negative economic impacts that add to direct negative effects of air pollution such as increased mortality and morbidity (Rizzi, De La Maza, Cifuentes \& Gómez, 2014). A continued decrease in international visitation to China is possible if no efforts are taken to address the ongoing issue of urban air pollution in China. It is therefore critical for the tourism sector to support the Chinese Government in their efforts to address air pollution. Recent research indicates that the awareness of the Chinese population is high, but individual commitment to support smog-reducing activities could be improved (Wang et al., 2015). Tourism can play an important role as an advocate for clean air, as an educator, and as a leading industry for implementing clean technology that reduces harmful emissions. Recent research on China tourism indicates that academics are increasingly keen to identify new technologies and behaviours to reduce the environmental impacts of tourism (Zhong, Deng, Song \& Ding, 2011). It is important that industry practice follows. 
The second contribution of this research lies in the recognition of the importance of the affective dimensions of both destination image and risk perceptions, reinforcing recent trends of moving beyond cognitive processes (Trumbo et al., 2016), but analyse emotions as in related environmental research, for example in the context of climate change risk perceptions (Shakeela \& Becken, 2015) or hurricane risk (Trumbo et al., 2016). Respondents in this research expressed negative feelings in general (affective image), and in relation to air pollution in particular (affective risk). Poor air quality and haze stain the beauty of natural and man-made tourist attractions, and are likely to influence how tourists experience a place. In fact, the negative impact of air pollution on visibility and aesthetic landscapes has previously found to be substantial (Rizzi et al., 2014). In addition, air pollution poses a latent health risk and is repulsive to human senses. As such, air pollution differs from lake pollution investigated by Ryan et al. (2010) who argued that even a polluted lake can provide an aesthetically pleasing tourism experience. In this present research, instead, the new construct 'feelings toward air quality' had a significant influence on all aspects of destination image concept - cognitive, affective and conative image (travel intention); highlighting the need to consider risk-as-feelings when examining image.

Importantly, and relevant for practitioners, the importance of affective dimensions became particularly evident when investigating intention to visit China. This paper verifies that future visitation is influenced by both affective destination image and affective risk perception. In contrast, neither cognitive destination image nor cognitive risk perception exerted a measurable influence on respondents' intention to visit. This finding differs from similar research undertaken in Japan following the Fukushima disaster where both risk perceptions and cognitive image influenced the likelihood of revisitation (Chew \& Jahari, 2014), but it confirms research on political stereotypes that highlighted the dominating effect of affective destination image (Chen et al., 2016). In other words, pure knowledge of the existence of air 
pollution, whether framed as a destination attribute or travel risk, did not deter potential travellers, but negative sensations and arousals did. Thus, destination marketing organisations and tour operators need to expand their communication and promotion material to specifically include stimulating positive arousals, whilst at the same time relieving negative sensations (e.g. fear or worry). It is possible that current approaches that focus on profiling well-known attractions are not sufficient to increase intention to visit, especially amongst infrequent travellers who are mostly holding an organic image easily influenced by emotional messages (Chen et al., 2016).

Thirdly, this research makes an important theoretical contribution by shedding further light on the link between destination image and risk perceptions. The SEM showed that affective destination image is, indeed, influenced by both cognitive and affective risk perceptions (Chew \& Jahari, 2014). This is consistent with prior studies indicating that affective image has a low threshold for change, whereas cognitive destination image, which is only affected by affective risk perception, is more stable in the minds of tourists ( $\mathrm{Li}$ et al., 2009; Gartner \& Shen, 1992). The findings therefore confirm one of the central questions of this research, namely whether examining risk perceptions is adding substantial value when exploring questions of destination image (Chew \& Jahari, 2014). Future research could refine the measurements of both cognitive and affective risk perceptions, and explore systematically different types of travel risks and how they could undermine destination image. Finally, this research confirms that several factors moderate destination image, risk perceptions and intentions to visit perceptions. For example, people's personal experience with an environmental risk has been found to lead to greater awareness and risk aversion (Shakeela \& Becken, 2015). However, this present research found that frequent travel activity, while having generated higher levels of risk awareness, is associated with increased tolerance towards air pollution rather than decreased acceptance. In other words, frequent 
travellers felt less frightened or concerned when thinking about China's air quality than other travellers. Moreover, those who had been to China previously held a more positive affective destination image compared with those who had not visited. It is possible that the nature of air pollution, and its varying intensity on different days, leads experienced travellers to believe that it is an acceptable risk, since possibly they had 'escaped without major harm' on previous visits. In this sense, past visits to China or other polluted destinations could be interpreted as reassuring, and give a greater locus of control (Loewenstein et al., 2001). Several other different between market segments were found. In this study, and in contrast to earlier research by Lepp and Gibson (2003), women were more resilient towards air pollution than men. Further, and in contrast to Schroeder et al (2013), who reported that younger travellers from the US had a higher risk perception than older travellers, this research found no differences between younger and older respondents in terms of cognitive risks. However, there were differences in terms of affective risk perceptions: younger travellers demonstrated more tolerance than older visitors. Conventionally, the older groups (aged 45 to 64) are the key market segments for China from both the US and Australia (CNTA, 2014), and this highlights the importance to ensure that negative feelings held by these older travellers are addressed by Chinese operators and marketing agencies.

Practically, given the tainted image, counter-branding is important for China. Engaging with autonomous and organic materials, for example through encouraging blogging from nonpolluted areas, could be an effective way to re-brand China. An example of counter-branding is the sumptuous and beautifully shot 2012 documentary 'A Bite of China', which has gained high popularity among its viewers. The sensational, informative, educational and entertaining series about nature, food and people of China even changed the image of its producer - China Central Television, a TV station widely perceived as obliging communist propaganda and transmitting low-quality soap operas (Thring, 2012). Positive effects of modifying risk 
perceptions by presenting attractive marketing material (Lepp et al., 2011) could be purposefully exploited. In developing such approaches, it should be noted that China is a country with vast territory and diversified tourist resources. Although urban cities suffer sever air pollution, there are scenic spots that are not majorly affected by pollution. It is therefore advisable to brand China using a more diversified suite of images and materials.

This study has several limitations. It sampled potential tourists using online panels, which are not constructed on probability-based recruitment and thus have an under-coverage and higher non-response error (Baker et al., 2010). Further, ANOVAs and t-tests were used drawing on unbalanced sample sizes for different age groups and groups of past/frequent travel experiences, possibly impairing the reliability and generalizability of the comparison. An age bias due to a higher representation of senior respondents is possible. Despite these limitations, this study contributes to the body of image and risk literature by incorporating both the cognitive and affective dimensions of the two constructs into one model to assess their relationships and impacts on travel intention. As a result, this study points out several research avenues. Further research could examine risk-as-feeling for other environmental risks in relation to air pollution. In particular, infrequent travellers may require more attention in terms of their organic image and risk perceptions and whether these are transmitted to more frequent travellers via word-of-mouth. Thus, studies could specifically explore the utilization of organic sources of information (e.g. travel blogs, social media) on cognitive and affective image and risk perceptions.

\section{Conclusion}

Building on previous bodies of knowledge on destination image and risk perceptions, this research explored China's destination image held by US and Australian residents, with a particular focus on air pollution. Traditionally, China's image is built around cultural attractions, history and food, but more recently negative influences and travel risks have 
begun to undermine the image. This present research provided evidence of how air pollution is affecting China's destination attractiveness. One of the key findings was that potential travellers' feelings about air quality (affective risk perception) were negative, and these feelings appeared to erode destination image and negatively affected intention to visit. Thus by establishing the critical importance of affective dimensions (both image and risk), the study added to the body of theory on destination image and choice, building on earlier calls for broadening cognitive approaches to dual-process ones. Furthermore, this research provided empirical evidence for the need to consider risky and deterring factors in destination image studies; thus theoretically linking risk and image as two distinct but enhancing concepts.

Suggestions for addressing the barrier of air pollution to growing international tourism in China have been provided, including a more proactive stance on environmental protection by tourism stakeholders, and targeted counter-branding campaigns. Future research should explore the role of social media in influencing organic or induced image, the importance of non-travellers as part of a destination discourse, and change factors that might reverse negative perceptions or feelings. Such research, possibly through a qualitative approach, should shed additional light on the role and impact of the 'four key ingredients' of destination choice, namely image (cognitive and affective) and risk perceptions (cognitive and affective). 


\section{References}

Anaman, K.A. \& Looi, C.N. (2000). Economic impact of haze-related air pollution on the tourism industry in Brunei Darussalam. Economic Analysis and Policy, 30(2), 133-144.

Anderson, J.C. \& Gerbing, D.W. (1982). Some Methods for Respecifying Measurement Models to Obtain Unidimensional Construct Measurement. Journal of Marketing Research, 19(4), 453-460.

Bagozzi, R. P. \& Yi, Y. (2011). Specification, evaluation, and interpretation of structural equation models. Journal of the Academy of Marketing Science, 40(1), 8-34.

Baker, R., Blumberg, S. J., Brick, J. M., Couper, M. P., ... Zahs, D. (2010). Research Synthesis AAPOR Report on Online Panels. Public Opinion Quarterly, 1-71. Retrieved (20/09/15) http://poq.oxfordjournals.org/content/early/2010/10/19/poq.nfq048.full.pdf

Baloglu, S. \& Brinberg, D. (1997). Affective images of tourism destinations. Journal of Travel Research, 35(4), 11-15.

Baloglu, S. \& McCleary, K.W. (1999). A model of destination image formation. Annals of Tourism Research, 26(4), 868-897.

BBC News (2014). Paris Mayor Anne Hidalgo calls for ban on diesel cars by 2020. Available (22/04/15) http://www.bbc.com/news/world-europe-30368504

Beerli, A. \& Martín, J.D. (2004). Tourists' characteristics and the perceived image of tourist destinations: a quantitative analysis - a case study of Lanzarote, Spain. Tourism Management, 25(5), 623-636.

Chen, C., Lai, Y., Petrick, J., \& Lin, Y. (2016). Tourism between divided nations: An examination of stereotyping in destination image. Tourism Management, 55, 25-36.

Cheung, C. \& Law, R. (2001). The impact of air quality on tourism: the case of Hong Kong. Pacific. Tourism Review, 5(1), 69-74.

Cheng, D.N., Zhou, Y.B., Wei., X.D., \& Wu, J. (2015). A study on the environmental risk perceptions of inbound tourists for China using negative IPA assessment. Tourism Tribune, 30 (1), 54-62.

Chew, E.Y.T. \& Jahari, S.A. (2014). Destination image as a mediator between perceived risks and revisit intention: A case of post-disaster Japan. Tourism Management, 40, 382393. 
CNTA (2014). China National Tourism Administration Tourism Statistics. Retrieved (01/11/15) http://en1.cnta.gov.cn/html/tjzlm/index.html.

Crompton, J.L. (1979). An assessment of the image of Mexico as a vacation destination and the influence of geographical location upon that image. Journal of Travel Research, 17(4), $18-23$.

Dann, G.M. (1996). Tourists' images of a destination-an alternative analysis. Journal of Travel \& Tourism Marketing, 5(1-2), 41-55.

Del Bosque, I.R. \& Martín, H.S. (2008). Tourist satisfaction a cognitive-affective model. Annals of Tourism Research, 35(2), 551-573.

Douglas, M. \& Wildavsky, A.B. (1982). Risk and Culture: An essay on the selection of technical and environmental dangers. Berkeley: University of California Press.

Echtner, C.M. \& Ritchie, J.B. (1993). The measurement of destination image: An empirical assessment. Journal of Travel Research, 31(4), 3-13.

Echtner, C. M., \& Ritchie, J. B. (2003). The meaning and measurement of destination image. Journal of Tourism Studies, 14(1), 37-48.

Fakeye, P.C. \& Crompton, J.L. (1991). Image differences between prospective, first-time, and repeat visitors to the Lower Rio Grande Valley. Journal of Travel Research, 30(2), $10-16$.

Fornell, C. \& Larcker D.F. (1981). Evaluating structural equation models with unobservable variables and measurement error. Journal of Marking Research, 18 (1), 39-50

Gallarza, M.G., Saura, I.G., \& García, H.C. (2002). Destination image: towards a conceptual framework. Annals of Tourism Research, 29(1), 56-78.

Gao, J., Ma, Y.F., \& Wu, B.H. (2010). Defects of China's inbound tourism from foreign tourists' perspectives: An analysis based on grounded theory research paradigm. Tourism Science, 24(5), 49-55.

Gartner, W.C. (1994). Image formation process. Journal of Travel \& Tourism Marketing, 2(2-3), 191-216.

Gartner, W.C., \& Shen, J. (1992). The impact of Tiananmen Square on China's tourism image. Journal of Travel Research, 30(4), 47-52.

George, R. (2003). Tourist's perceptions of safety and security while visiting Cape Town. Tourism Management, 24(5), 575-585. 
Gu, H. \& Ryan, C. (2008). Place attachment, identity and community impacts of tourismthe case of a Beijing hutong. Tourism Management, 29(4), 637-647.

Hair, J. F., Anderson, R. E., Tatham, R. L., \& Black, W. C. (2010). Multivariate analysis $\left(7^{\text {th }}\right.$ ed.). Prentice Hall International.

Internet World Stats (2014). Usage and Population Statistics. Retrieved (20/04/2015) http://www.internetworldstats.com/stats6.htm

Jeuring, J. \& Becken, S. (2013). Tourists and extreme weather events. The role of Locus of Responsibility in protective behaviour. Tourism Management, 37, 193-202.

Jöreskog, K. G. (1993). Testing structural equation models. Sage focus editions, 154, 294294.

Konecnik, M. (2002). The image as a possible source of competitive advantage of the destination. The case of Slovenia. Tourism Review, 57(1/2), 6-12.

Larsen, S., Brun, W., \& Øgaard, T. (2009). What tourists worry about-Construction of a scale measuring tourist worries. Tourism Management, 30(2), 260-265.

Loewenstein, G.F., Weber, E.U., Hsee, C.K., \& Welch, N. (2001). Risk as Feelings. Psychological Bulletin, 127(2), 267-286.

Law, R. \& Cheung, C. (2007). Air quality in Hong Kong: a study of the perception of international visitors. Journal of Sustainable Tourism, 15(4), 390-401.

Lawton, L. \& Weaver, D. (2015). Using residents' perceptions research to inform planning and management for sustainable tourism: a study of the Gold Coast Schoolies Week, a contentious tourism event. Journal of Sustainable Tourism, 23(5), 660-682.

Lepp, A. \& Gibson, H. (2003). Tourist roles, perceived risk and international tourism. Annals of Tourism Research, 30(3), 606-624.

Lepp, A., Gibson, H., \& Lane, C. (2011). Image and perceived risk: A study of Uganda and its official tourism website. Tourism Management, 32(3), 675-684.

Li, X. (2014). Country’s alarming tourism deficit. China Daily Europe, 2014-10-31.

Retrieved (20/11/15) http://europe.chinadaily.com.cn/epaper/201410/31/content_18834010.htm.

Li, X., Pan, B., Zhang, L., \& Smith, W.W. (2009). The effect of online information search on image development insights from a mixed-methods study. Journal of Travel Research, 48(1), 45-57. 
Line, N.D. \& Hanks, L. (2015). The effects of environmental and luxury beliefs on intention to patronize green hotels: the moderating effect of destination image. Journal of Sustainable Tourism, DOI:10.1080/09669582.2015.1091467.

Maser, B. \& Weiermair, K. (1998). Travel decision-making: From the vantage point of perceived risk and information preferences. Journal of Travel \& Tourism Marketing, 7(4), 107-121.

Nadeau, J., Heslop, L., O’Reilly, N., \& Luk, P. (2008). Destination in a country image context. Annals of Tourism Research, 35(1), 84-106.

Oltra, C. \& Sala, R. (2014). A review of the social research on public perception and engagement practices in urban air pollution. Informes Técnicos Ciemat. Retrieved $(20 / 03 / 16)$

http://www.iaea.org/inis/collection/NCLCollectionStore/_Public/45/046/45046419.pdf

Pan, B. \& Li, X. (Robert) (2011). The long tail of destination image and online marketing. Annals of Tourism Research, 38(1), 132-152.

Pike, S. \& Ryan, C. (2004). Destination positioning analysis through a comparison of cognitive, affective, and conative perceptions. Journal of Travel Research, 42(4), 333-342.

Qi, C. X., Gibson, H. J., \& Zhang, J.J. (2009). Perceptions of risk and travel intentions: the case of China and the Beijing Olympic Games. Journal of Sport \& Tourism, 14(1), 43-67.

Reisinger, Y. \& Mavondo, F. (2006). Cultural differences in travel risk perception. Journal of Travel \& Tourism Marketing, 20(1), 13-31.

Richter, L.K. (2003). International tourism and its global public health consequences. Journal of Travel Research, 41(4), 340-347.

Rizzi, L.I., De La Maza, C., Cifuentes, L.A., \& Gómez, J. (2014). Valuing air quality impacts using stated choice analysis: Trading off visibility against morbidity effects. Journal of Environmental Management, 146, 470-480.

Russell, J.A., Ward, L.M., \& Pratt, G. (1981). Affective Quality Attributed to Environments A Factor Analytic Study. Environment and Behavior, 13(3), 259-288.

Ryan, C., Gu, H., \& Chon, K. (2010). Tourism to polluted lakes: issues for tourists and the industry. An empirical analysis of four Chinese lakes. Journal of Sustainable Tourism, 18(5), 595-614.

Sáenz-de-Miera, O. \& Rosselló, J. (2013). Tropospheric ozone, air pollution and tourism: a case study of Mallorca. Journal of Sustainable Tourism, 21(8), 1232-1243. 
Sajjad, F., Noreen, U., \& Zaman, K. (2014). Climate change and air pollution jointly creating nightmare for tourism industry. Environmental Science and Pollution Research, 1-16.

Santos, J. (1998). The role of tour operators' promotional material in the formation of destination image and consumer expectations: The case of the People's Republic of China. Journal of Vacation Marketing, 4(3), 282-297.

Schroeder, A., Pennington-Gray, L., Kaplanidou, K., \& Zhan, F. (2013). Destination risk perceptions among U.S. residents for London as the host city of the 2012 Summer Olympic Games. Tourism Management, 38, 107-119.

Shakeela, A. \& Becken, S. (2015). Social amplification and attenuation of climate change risk in a vulnerable tourism destination. Journal of Sustainable Tourism, 23(1), 65-84.

Shani, A., Chen, P.-J., Wang, Y., \& Hua, N. (2010). Testing the impact of a promotional video on destination image change: application of China as a tourism destination. International Journal of Tourism Research, 12(2), 116-133.

Shim, M. \& You, M. (2015). Cognitive and affective risk perceptions toward food safety outbreaks: mediating the relation between news use and food consumption intention. Asian Journal of Communication, 25(1), 48-64.

Sirakaya, E., Sheppard, A.G., \& McLellan, R.W. (1997). Assessment of the relationship between perceived safety at a vacation site and destination choice decisions: extending the behavioral decision-making model. Journal of Hospitality \& Tourism Research, 21(2), 110.

Sönmez, S.F. \& Graefe, A.R. (1998). Determining future travel behavior from past travel experience and perceptions of risk and safety. Journal of Travel Research, 37(2), 171-177.

Steenkamp, J.E.M. \& van Trijp, H.C.M. (1991). The use of lisrel in validating marketing constructs. International Journal of Research in Marketing, 8(4), 283-299.

Stern, E. \& Krakover, S. (1993). The formation of a composite urban image. Geographical Analysis, 25(2), 130-146.

Thring, O. (2012). A bite of China: the finest food TV ever? Retrieved (30/04/15) http://www.oliverthring.com/2012/09/a-bite-of-china-the-finest-food-tv-ever.html Trumbo, C.W., Peek, L., Meyer, M.A., Marlatt, H.L., Gruntfest, E., McNoldy, B.D., \& Schubert, W.H. (2016). A cognitive-affective scale for hurricane risk perception. Risk Analysis, doi: 10.1111/risa.12575. 
United Nations World Tourism Organisation (2014). Tourism Barometer. Vol 13, April 2015. Madrid.

Ward, L. M. \& Russell, J. A. (1981). The psychological representation of molar physical environments. Journal of Experimental Psychology, 110(2), 121.

Xiao, H. \& Mair, H.L. (2006). “A Paradox of Images”. Representation of China as a tourist destination. Journal of Travel \& Tourism Marketing, 20(2), 1-14.

Xua, H., Cuia, Q., Sofield, T., \& Lib, F.M.S. (2014). Attaining harmony: understanding the relationship between ecotourism and protected areas in China. Journal of Sustainable Tourism, 22(8), 1131-1150.

Wang, Y., Sun, M., Yang, X., \& Yuan, X. (2015). Public awareness and willingness to pay for tackling smog pollution in China: a case study. Journal of Cleaner Production, 112(2), $1627-1634$.

Williams, A. \& Baláž, V. (2015). Tourism risk and uncertainty: theoretical reflections. Journal of Travel Research, 54(3), 271-287.

World Health Organisation Western Pacific Region (2015). Air pollution. China. Fact Sheet. Retrieved (27/04/15) http://www.wpro.who.int/china/mediacentre/factsheets/air_pollution/en/

Zand, B. (2015). Chinas Zensur macht Smog-Filmerin mundtot. SPIEGEL Online. Retrieved (19/04/15) www.spiegel.de/wissenschaft

Zhong, L., Deng, J., Song, Z., \& Ding, P. (2011). Research on environmental impacts of tourism in China: Progress and prospect. Journal of Environmental Management, 92, 2972-2983. 


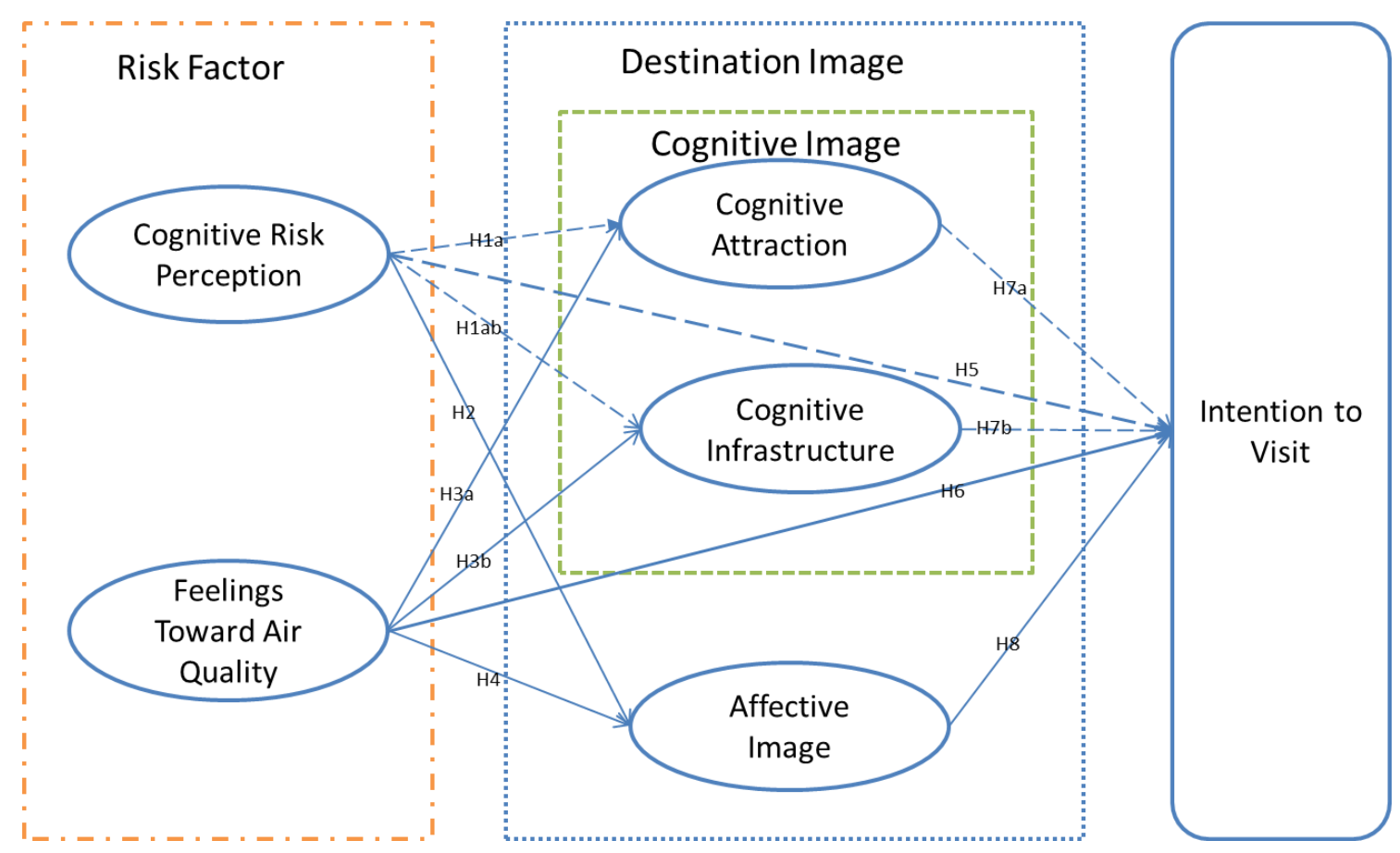

Figure $1^{1}$ Framework showing the relationships between cognitive and affective risk, destination image dimensions and intention to visit.

1 The lines between the variables indicate the hypothesized relationships among the independent and dependent variables. The dotted lines refer to insignificant relationships as a result of the structural equation modeling presented in this paper. 
Table 1 Demographic profile of respondents $(N=610)$

\begin{tabular}{|c|c|c|c|c|c|c|c|}
\hline \multirow[t]{2}{*}{ Variable } & & \multicolumn{2}{|c|}{ USA } & \multicolumn{2}{|l|}{$\mathrm{AU}$} & \multicolumn{2}{|c|}{ OVERALL } \\
\hline & & $\mathrm{N}$ & $\%$ & $\mathrm{~N}$ & $\%$ & $\mathrm{~N}$ & $\%$ \\
\hline \multirow[t]{3}{*}{ Gender } & Male & 148 & 48.5 & 157 & 51.5 & 305 & 50 \\
\hline & Female & 157 & 51.5 & 148 & 48.5 & 305 & 50 \\
\hline & Under 24 & 18 & 5.9 & 11 & 3.6 & 29 & 4.7 \\
\hline \multirow[t]{3}{*}{ Age } & $25-39$ & 79 & 25.9 & 76 & 24.9 & 155 & 25.4 \\
\hline & $40-54$ & 69 & 22.6 & 71 & 23.3 & 140 & 23.0 \\
\hline & 55 or more & 139 & 45.6 & 147 & 48.2 & 286 & 46.9 \\
\hline \multirow{4}{*}{$\begin{array}{l}\text { Education } \\
\text { background }\end{array}$} & Primary/basic education & 14 & 4.6 & 14 & 4.6 & 28 & 4.6 \\
\hline & $\begin{array}{l}\text { Complete } \\
\text { secondary/high school }\end{array}$ & 126 & 41.3 & 113 & 37.0 & 239 & 39.2 \\
\hline & $\begin{array}{l}\text { Completed } \\
\text { college/university } \\
\text { diploma/degree }\end{array}$ & 123 & 40.3 & 143 & 46.9 & 266 & 43.6 \\
\hline & $\begin{array}{l}\text { Completed postgraduate } \\
\text { degree }\end{array}$ & 42 & 13.8 & 35 & 11.5 & 77 & 12.6 \\
\hline \multirow{3}{*}{$\begin{array}{l}\text { International travel } \\
\text { experience }\end{array}$} & Frequently & 29 & 9.5 & 51 & 16.7 & 80 & 13.1 \\
\hline & Occasionally & 112 & 36.7 & 170 & 55.7 & 282 & 46.2 \\
\hline & Never & 164 & 53.8 & 84 & 27.5 & 248 & 40.7 \\
\hline \multirow{2}{*}{$\begin{array}{l}\text { Have you ever } \\
\text { visited China }\end{array}$} & Ever & 37 & 12.1 & 85 & 27.9 & 122 & 20 \\
\hline & Never & 268 & 87.9 & 220 & 72.1 & 488 & 80 \\
\hline \multirow{5}{*}{$\begin{array}{l}\text { Intention to visit } \\
\text { China }\end{array}$} & Definitely not & 139 & 45.6 & 91 & 29.8 & 230 & 37.7 \\
\hline & Probably not & 46 & 15.1 & 56 & 18.4 & 102 & 16.7 \\
\hline & Neutral & 54 & 17.7 & 84 & 27.5 & 138 & 22.6 \\
\hline & Probably & 37 & 12.1 & 46 & 15.1 & 83 & 13.6 \\
\hline & Definitely will & 29 & 9.5 & 28 & 9.2 & 57 & 9.3 \\
\hline
\end{tabular}



Table 2 Overall Measurement Model - Cognitive Image (Infrastructure \& Attractions), Affective Image, Feelings toward Air Quality, and Risk Perception

\begin{tabular}{|c|c|c|c|c|c|c|c|}
\hline & $\begin{array}{l}\text { Overall } \\
\text { mean }\end{array}$ & $\begin{array}{l}\text { Std. } \\
\text { Dev }\end{array}$ & Estimate & SMC & C.R. & $\mathbf{C R}$ & AVE \\
\hline Cognitive attractions & & & & & & .92 & .79 \\
\hline Q8_2 Historic & 4.28 & .933 & 0.946 & 0.896 & 35.316 & & \\
\hline Q8_1 Cultural & 4.23 & .954 & 0.892 & 0.796 & & & \\
\hline Q8_3 Scenery/natural & 4.22 & .989 & 0.822 & 0.676 & 27.428 & & \\
\hline Cognitive infrastructure & & & & & & .90 & .57 \\
\hline Q8_7 Accommodation & 4.02 & 1.11 & 0.864 & 0.746 & 22.634 & & \\
\hline Q8_8 Transportation & 3.94 & 1.194 & 0.85 & 0.723 & 22.235 & & \\
\hline Q8_4 Shopping & 3.93 & 1.208 & 0.77 & 0.593 & & & \\
\hline Q8_5 Nightlife and entertainment & 3.85 & 1.297 & 0.715 & 0.512 & 22.775 & & \\
\hline Q8_9 People & 3.86 & 1.189 & 0.699 & 0.488 & 17.66 & & \\
\hline Q8_6 Food & 3.94 & 1.150 & 0.694 & 0.482 & 17.556 & & \\
\hline Q8_10 Hygiene & 3.52 & 1.381 & 0.679 & 0.461 & 17.087 & & \\
\hline Q8_12 Unpolluted environment & 3.11 & 1.450 & & & & & \\
\hline Q8_11 Clean air & 2.77 & 1.520 & & & & & \\
\hline Affective destination image & & & & & & .92 & .74 \\
\hline Q9_1 Displeased - Pleased & 3.48 & 1.143 & 0.879 & 0.772 & 28.453 & & \\
\hline Q9_2 Bored - Stimulated & 3.65 & 1.109 & 0.873 & 0.761 & 28.124 & & \\
\hline $\begin{array}{l}\text { Q9_5 Physically/Mentally Unwell - } \\
\text { Well }\end{array}$ & 3.50 & 1.103 & 0.861 & 0.741 & & & \\
\hline Q9_3 Distressed - Relaxed & 3.34 & 1.146 & 0.819 & 0.67 & 25.257 & & \\
\hline Q9_4 Indifferent - Exciting & 3.55 & 1.231 & & & & & \\
\hline Risk perception & & & & & & .91 & .68 \\
\hline Q10_4 Hygiene & 3.45 & 1.393 & 0.904 & 0.817 & 20.165 & & \\
\hline Q10_3 Food & 3.28 & 1.413 & 0.86 & 0.74 & 19.367 & & \\
\hline Q10_2 Transportation & 3.36 & 1.358 & 0.824 & 0.679 & 18.648 & & \\
\hline Q10_5 General Level Of Safety & 3.35 & 1.427 & 0.821 & 0.674 & 18.583 & & \\
\hline Q10_1 Air Quality & 3.75 & 1.382 & 0.687 & 0.472 & & & \\
\hline Feelings toward air quality & & & & & & .92 & .67 \\
\hline Q11_2 Frightened - Reassured & 2.71 & 1.061 & 0.915 & 0.837 & 29.002 & & \\
\hline Q11_1 Sick - Healthy & 2.60 & 1.143 & 0.862 & 0.744 & 26.551 & & \\
\hline $\begin{array}{l}\text { Q11_4 Out Of Control - Under } \\
\text { Control }\end{array}$ & 2.78 & 1.107 & 0.84 & 0.706 & & & \\
\hline Q11_3 Concerned - Unconcerned & 2.37 & 1.141 & 0.804 & 0.647 & 23.794 & & \\
\hline Q11_5 Acceptable - Unacceptable & 2.60 & 1.385 & 0.656 & 0.43 & 17.937 & & \\
\hline $\begin{array}{l}\text { Air quality will affect my decision to } \\
\text { visit }\end{array}$ & 3.37 & 1.250 & & & & & \\
\hline
\end{tabular}

Note: Values of mean and std. dev are from descriptive analysis of all observed variables. Values of estimates, SMC, C.R., CR and AVE are the results of CFA. Model fit indices of CFA: $\chi^{2}=724.55, \mathrm{df}=240, \chi^{2} / \mathrm{df}=3.019, \mathrm{GFI}=.908, \mathrm{CFI}=.955$, RMSEA $=.058$. Three indicators were removed from measurement scales based on low factor loadings and high correlations onto measurements of other latent variables: clean air, unpolluted environment, and indifferent-exciting. 
Table 3 Implied Correlations for All Latent Variables

\begin{tabular}{llllll}
\hline & $\begin{array}{l}\text { Risk } \\
\text { Perception }\end{array}$ & $\begin{array}{l}\text { Affective } \\
\text { Image }\end{array}$ & Core Attractions & Infrastructure & $\begin{array}{l}\text { Feelings } \\
\text { toward Air } \\
\text { quality }\end{array}$ \\
\hline Risk Perception & 1 & & & & \\
Affective Image & -0.289 & 1 & & & \\
Core Attractions & -0.04 & 0.503 & 1 & 1 & \\
Infrastructure & -0.092 & 0.45 & 0.687 & 0.331 & 1 \\
Feelings toward & -0.31 & 0.506 & 0.155 & & \\
Air quality & & & & 3.87 & 2.61 \\
Mean & 3.44 & 3.5 & 4.24 & 1.22 & 1.17 \\
St. Dev & 1.4 & 1.45 & 0.96 & 0.57 & 0.67 \\
AVE & 0.68 & 0.74 & 0.79 & 0.9 & 0.92 \\
CR & 0.91 & 0.92 & 0.92 & & \\
\hline
\end{tabular}


Table 4 The Structural Model - Hypothesis Testing

\begin{tabular}{llllllll}
\hline $\begin{array}{l}\text { Hypo- } \\
\text { thesis }\end{array}$ & $\begin{array}{l}\text { Independent } \\
\text { Variables }\end{array}$ & $\begin{array}{l}\text { Dependent } \\
\text { Variables }\end{array}$ & Estimate & S.E. & C.R. & $\begin{array}{l}\text { P- } \\
\text { Value }\end{array}$ & $\begin{array}{l}\text { Hypo- } \\
\text { thesis } \\
\text { supported }\end{array}$ \\
\hline H1a & Risk Perception & CI/ Attractions & 0.009 & 0.041 & 0.2 & 0.841 & No \\
H1b & Risk Perception & CI/ infrastructure & 0.005 & 0.045 & 0.118 & 0.906 & No \\
H2 & Risk Perception & Affective Image & -0.147 & 0.046 & -3.562 & $* * *$ & Yes \\
H3a & Feeling air quality & CI/Attractions & 0.158 & 0.042 & 3.433 & $* * *$ & Yes \\
H3b & Feeling air quality & CI/ infrastructure & 0.334 & 0.047 & 7.209 & $* * *$ & Yes \\
H4 & Feeling air quality & Affective Image & 0.461 & 0.049 & 10.623 & $* * *$ & Yes \\
H5 & Risk Perception & Intention to visit & 0.048 & 0.057 & 1.186 & 0.236 & No \\
H6 & Feeling air quality & Intention to visit & 0.128 & 0.069 & 2.696 & 0.007 & Yes \\
H7a & CI/ Attractions & Intention to visit & -0.03 & 0.095 & -0.51 & 0.61 & No \\
H7b & CI/ infrastructure & Intention to visit & 0.019 & 0.081 & 0.33 & 0.741 & No \\
H8 & Affective Image & Intention to visit & 0.441 & 0.069 & 8.113 & $* * *$ & Yes \\
\hline
\end{tabular}

Model fit indices: $\chi 2=895.10, \mathrm{df}=261, \chi 2 / \mathrm{df}=3.43, \mathrm{GFI}=.9, \mathrm{CFI}=.943$, $\mathrm{RMSEA}=.063$ 
Table 5 ANOVA - Differences among Country, Gender, Age, Travel Experience, and Past Visitation to China

\begin{tabular}{|c|c|c|c|c|c|c|}
\hline & Mean & Mean & Mean & Mean & $\begin{array}{l}\text { ANOVA } \\
\text { sig. 2-tails }\end{array}$ & Post Hoc (LSD) \\
\hline Country of residence & USA $n=305$ & $\mathbf{A U} n=305$ & & & & \\
\hline Attraction & 4.17 & 4.33 & & & .001 & \\
\hline Affective destination image & 3.4 & 3.61 & & & .009 & \\
\hline Intention to visit China & 2.25 & 2.55 & & & .005 & \\
\hline Gender & Male $n=305$ & Female $n=305$ & & & & \\
\hline Feelings toward air quality & 2.49 & 2.73 & & & .01 & \\
\hline Age group & $\begin{array}{l}\text { Under } 24 \\
\mathbf{n}=29\end{array}$ & $25-39 n=155$ & $\begin{array}{l}40-54 \\
n=140\end{array}$ & $\begin{array}{l}55 \text { or more } \\
n=286\end{array}$ & & \\
\hline Attraction & 3.7 & 4.1 & 4.22 & 4.39 & .000 & 55 or more $>25-39(.001)$ \\
\hline Feelings toward Air Quality & 2.69 & 2.82 & 2.59 & 2.50 & .006 & 55 or more $<25-39(.006)$ \\
\hline Intention to visit China & 2.83 & 2.90 & 2.36 & 2.11 & .000 & $25-39>40-54(.000) ; \quad 25-39>55$ or more $(.000)$ \\
\hline Have you visited China? & Ever $n=122$ & Never $n=488$ & & & & \\
\hline Attraction & 4.54 & 4.17 & & & .000 & \\
\hline Affective destination image & 3.99 & 3.39 & & & .000 & \\
\hline Intention to visit China & 3.46 & 2.14 & & & .000 & \\
\hline $\begin{array}{l}\text { International travel } \\
\text { experience }\end{array}$ & $\begin{array}{l}\text { Frequent } \\
\mathbf{n}=\mathbf{8 0}\end{array}$ & $\begin{array}{l}\text { Occasional } \\
\mathbf{n}=\mathbf{2 8 2}\end{array}$ & $\begin{array}{l}\text { Never } \\
\mathrm{n}=\mathbf{2 4 8} \\
\end{array}$ & & & \\
\hline Attraction & 4.3 & 4.37 & 4.09 & & .001 & Never < frequent (.006); never < occasional (.000) \\
\hline Affective image & 3.79 & 3.71 & 3.17 & & .000 & Never < frequent (.000); never < occasional (.000) \\
\hline Feelings toward Air quality & 2.89 & 2.67 & 2.46 & & .000 & Never < frequent $(.000)$; never < occasional $(.005)$ \\
\hline Risk perception & 3.64 & 3.29 & 3.55 & & .006 & $\begin{array}{l}\text { Occasional < frequent }(.016) \text {; occasional < never } \\
(.007)\end{array}$ \\
\hline Intention to visit China & 3.53 & 2.72 & 1.68 & & .000 & $\begin{array}{l}\text { Never < frequent }(.000) \text {; never < occasional } \\
(.000) \text {; occasional < frequent }(.000)\end{array}$ \\
\hline
\end{tabular}


